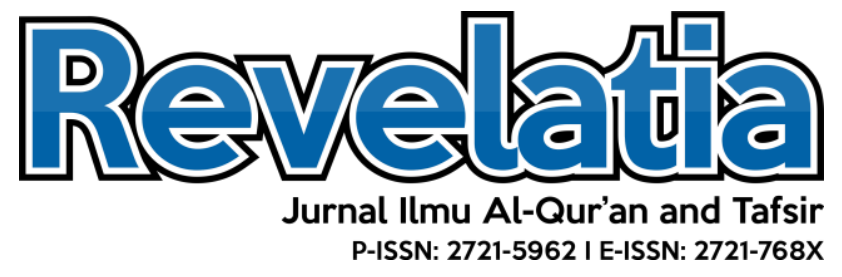

\title{
Ulama dalam Penguatan Politik Identitas Perspektif Al-Qur'an
}

\author{
Wardatur Rohmah \\ Mahasiswi Prodi IQT, IAIN Madura, \\ Email:wardatur@gmail.com \\ Nafilah Sulfa \\ Pengurus PP. Ziyadatut Taqwa Tlanakan Pamekasan, \\ Email: nafilahsulfa@yahoo.com
}

\begin{abstract}
Abstrak:
'Ulama are commanding religious figures with far-reaching knowledge; however, currently the term 'ulama is distorted by unscrupulous people. Frequently, Ulama's behaviors do not reflect their prestige as Prophet's heir even though having a number of fanatical adherents. Their fatwa has authoritative influence in establishing post-truth narration. It can cause a horizontal gap and segregation in society if their fatwas are not true. This crisis affected by the increase of identity politics during pre-post political contestation. Meanwhile, the hugest disadvantages are beared by whose tend to believe in their thoughts and behaviors. We analyzed this phenomenon from the perspective of the Qur'an on the meaning of the term 'ulama and their role in identity politics involvement. We used sociological-normative and descriptive-phenomenological methods to reread some related verses. This study showed, for example, refered to Q.S. Ali 'Imran (3): 104, 'ulama are allowed to have an active and positive role in the sphere of politics.
\end{abstract}

\begin{abstract}
Abstrak
[Ulama merupakan sosok berpengetahuan agama yang luas dan berwibawa. Belakangan, istilah ulama terdistorsi oleh oknum-oknum bersikap arogan, fanatik cenderung ekstrem. Tidak jarang, muncul sosok yang dielu-elukan sebagai ulama, memiliki pengikut fanatik, namun sosoknya tak mencerminkan sikap ideal pewaris Nabi. Terlebih, sosok yang kadung disebut ulama tersebut telah berperan dalam membentuk narasi post-truth, opini yang dianggap benar lebih karena ikatan emosional meskipun jauh dari fakta. Akibatnya, terbentuknya sekat dan segregasi horizontal di tengah masyarakat, yang sewaktu-waktu dapat mengancam sendi-sendi kesatuan bangsa. Fenomena tersebut merupakan akibat dari menguatnya politik identitas yang menguat pra-pasca kontestasi politik. Kerugian terbesar dirasakan oleh masyarakat awam yang cenderung taklid terhadap sosok ulama. Penulis menganalisis fenomena tersebut melalui perspektif Al-Qur'an terhadap makna ulama dan peran mereka dalam memainkan politik identitas. Untuk mencapai tujuan itu,
\end{abstract}


penulis menggunakan metode sosiologis-normatif dan deskriptif-fenomenologis untuk membaca ulang ayat-ayat terkait. Hasil penelitian menunjukkan kebolehan ulama berperan di dalam dunia politik yang seyogianya memberikan citra baik berpolitik sebagaimana, misalnya, spirit dari Q.S. Ali ‘Imran (3): 104.]

Kata Kunci: Politik Identitas; Ulama; Pasca Kebenaran 


\section{PENDAHULUAN}

Indonesia merupakan negara dengan penduduk yang memiliki tingkat pluralitas tinggi, dari multi-etnis, multi-agama, hingga multi-suku dan keberagaman lainnya. Keberagaman tersebut, selain menjadi anugerah juga merupakan tantangan besar bagi bagi bangsa Indonesia dalam membangun kehidupan berbangsa yang harmonis. Di samping kebermanfaatannya, keberagaman tersebut berpotensi menjadi sebuah konflik yang berkepanjangan. Umat muslim, sebagai penduduk mayoritas, diharapkan peranannya dalam menjaga kerukunan hidup dan persatuan bangsa, sebagai pengejawantahan cita-cita besar Islam yang rahmatan lil 'alamin. ${ }^{1}$ Nurcholis Majid menegaskan, Islam adalah agama kemanusiaan terbuka. Oleh karenanya, umat Islam harus menjunjung tinggi nilai-nilai kemanusiaan. Kesempurnaan iman kepada Allah hanya bisa terwujud jika dibareng dengan memuliakan sesame manusia sebagai ciptaan Allah. Iman yang tidak disertai sikap positif terhadap manusia belum merupakan iman dalam arti yang sebenarnya. ${ }^{2}$

Euforia kontestasi politik yang tengah dihadapi oleh masyarakat Indonesia, merupakan bukti terkini, semakin menguapnya penghayatan tentang keimanan. Kontestasi politik yang merupakan agenda tahunan sebagai konsekuensi logis dianutnya sistem demokrasi, malah menjadi ajang saling melontarkan tuduhan terhadap pihak yang dianggap lawan. Akibatnya, di tengah masyarakat, bertebaran berita-berita tak berdasar berupa hoax, ujaran kebencian, hingga tuduhan-tuduhan tak berdasar. Padahal, seharusnya demokrasi justru memberikan jaminan atas kebebasan berekspresi bagi individu sebagai perwujudan hak asasi manusia.

Fenomena ini merupakan dampak dari politik identitas yang tidak ideal dan kebablasan. Politik identitas adalah suatu mekanisme politik dengan melakukan pengorganisasian identitas, baik identitas politik maupun sosial, sebagai sumber dan sarana politiknya. Salah satu tujuannya adalah mendapat pengakuan dan perlakuan yang setara atas dasar hak-hak sebagai manusia dalam hal politik, ekonomi maupun sosialbudaya. ${ }^{3}$ Sayangnya, politik identitas yang dimainkan tidak lagi menjadikan etika sebagai pegangan. Hal ini dapat dilihat dari beberapa partisan politik yang bertransformasi menjadi provokator, pemfitnah dan penyebar isu tidak benar. Berita-berita negatif tersebut, kemudian menjadi konsumsi publik melalui berbagai media sosial. Akibatnya, lahirlah fenomena post-truth, kebenaran semu yang tercipta dari kebohongan yang

\footnotetext{
${ }^{1}$ Ngainun Na'im, "Abdurrahman Wahid: Universalisme Islam dan Toleransi", Kalam, No. 10, vol. 2, (Desember, 2016), 424-425.

${ }^{2}$ Franz Magnis Suseno, Sj, dkk. Agama, Keterbukaan dan Demokrasi: Harapan dan Tantangan, (Jakarta: Pusat Studi Agama, 2015) 4-5.

${ }^{3}$ Mohtar Ahboddin, "Menguatnya Politik Identitas di Ranah Lokal”, Jurnal Studi Pemerintahan, vol. 3, no. 1 (Februari, 2012), 119.
} 
dihembuskan secara massif dan terstruktur. Dampaknya, terjadi penggiringan opini secara masif yang berakibat pada terjadinya segmentasi di tengah-tengah masyarakat. ${ }^{4}$

Ulama, alih-alih menjadi garda terdepan dalam menjernihkan pemikiran masyarakat yang mulai tersegmen, malah menjadi salah satu aktor pendukung penguatan politik identitas kebablasan. Selain menjadi obyek saling klaim dukungan, ulama berperan pula dalam penggiring opini publik. ${ }^{5}$ Contohnya, kasus ujaran kebencian dan pelecehan secara verbal pada salah satu paslon presiden tahun 2019 yang dilakukan oleh salah satu ulama Indonesia yang mengantarkannya ke dalam tahanan. Oleh karena itu, muncul polemik akibat penggiringan opini telah terjadi "kriminalisasi ulama". Masyarakat terpecah menjadi dua kubu; pro dan kontra. Kubu yang pro menuding telah terjadi kriminalisasi ulama, sementara kubu kontra lebih memilih untuk percaya penahanan ulama tersebut adalah murni kasus ujaran kebencian. ${ }^{6}$

Oleh karena itu, kajian tentang fenomena ulama dalam pusaran politik identitas menjadi penting, karena Al-Qur'an jelas memerintahkan umatnya untuk berbuat adil. Untuk menjawab dan menemukan solusi dari permasalahan tersebut dari sudut pandang Al-Qur'an, secara konseptual rumusan masalahnya ialah sebagai berikut: 1) Siapakah tokoh yang dapat dianggap sebagi ulama sejati? 2) Apa motif yang melatarbelakangi masuknya ulama dalam permainan politik identitas dan akibatnya? 3) Bagaimana AlQur'an memandang dan menyikapi fenomena masuknya ulama dalan pengutan politik identitas? Penulis mengangkat tiga hal tersebut karena ulama sejati adalah manusia yang tidak hanya pandai dalam ilmu agama tetapi disertai pula akhlak yang baik seperti Nabi. Selain itu, akan ditemukan bahwa setiap informasi yang disampaikan oleh beberapa ulama tersebut syarat dengan unsur kepentingan sebagai partisan politik. Bagi penulis, persoalan ini merupakan persoalan yang serius karena mengingat masyarakat Indonesia yang sangat meneladani ulama, bahkan taklid terhadap mereka. Tentunya, sangat berbahaya apabila fanatisme tersebut digiring menjadi suatu penggiringan opini yang rentan memicu timbulnya konflik.

\section{METODE PENELITIAN}

Kerangka teori yang penulis gunakan dalam tulisan ini dalam menganalisis masalah tersebut adalah pendekatan sosiologi-normatif dan metode deskriptiffenomenologi. Sosiologi merupakan ilmu yang mempelajari tentang struktur keterikatan masyarakat terhadap komunitasnya. Sedangkan pendekatan normatif diartikan sebagai upaya memahami sesuatu dari sudut pandang teks-teks agama. Jadi, pendekatan

${ }^{4}$ Khaerudin, Imawan, "Jurnalisme Data Resistensi Ruang Siberdi Era Post Truth", Jurnal Signal Unswagati Cirebon, vol. 6, no. 2, (Desember, 2018), 2.

5 Deasy Simandjuntak, "Indonesia: Politik Identitas Bayangi Pilpres 2019" dalam https://www.matamatapolitik.com/indonesia-politik-identitas-bayangi-pilpres-2019/ diakses pada 02 Februari 2019.

${ }^{6}$ Arbi Sumandoyo, "Pilpres 2019: Ulama Sana Versus Ulama Sini." Dalam https://tirto.id/pilpres2019-ulama-sana-versus-ulama-sini-cRT4, diakses pada 02 Februari 2019. 
sosiologi-normatif adalah upaya untuk menganalisis suatu fenomena berdasarkan sudut pandang struktur panghayatan masyarakat terhadap dirinya dalam sebuah masyarakat (komunitas) yang kemudian ditinjau pula dari sudut pandang teks-teks agama. ${ }^{7}$ Istilah fenomenologi dikenalkan oleh Edmund Husserl, berasal dari bahasa Yunani pahainomenon yang secara harfiah berarti gejala atau apa yang telah menampakkan diri. ${ }^{8}$ Dengan menggunakan metode ini, penulis mencoba mengidentifikasi bagaimana permainan politik identitas oleh ulama khususnya di Indonesia. Dengan demikian akan ditemukan pokok persoalan dan solusi Al-Qur'an mengenai hal ini.

\section{HASIL DAN PEMBAHASAN}

Dalam setiap agama dan kepercayaan yang berkembang, senantiasa terdapat figur panutan yang dijadikan teladan dan representasi bagi agama atau kepercayaan itu sendiri. Ulama yang menjadi frame baik dalam Islam. Figur ulama merupakan sosok yang mampu menjadi teladan dan panutan bagi masyarakat muslim di sepanjang kesejarahan agama ini. Oleh sebab itu, tingkat pemahaman dan ketundukan masyarakat muslim terhadap doktrin agama sangat tergantung pada figur ulama. Ulama berasal dari kata'âlim; orang yang berilmu atau yang berpengetahuan. Dalam bentuk isim fä'il, kata ini berarti telah berilmu atau telah mengetahui. Sehingga, ulama adalah orang-orang yang berilmu atau mengetahui. Hasan al-Bashri berpandangan bahwa ulama adalah orang yang takut kepada Allah, senang dengan yang disenangi Allah, dan meninggalkan apa yang dibenci oleh Allah. Maka, secara sosiologis keulamaan seseorang dapat dilihat dari integritas, kualitas keilmuan dan kredibilitas kesalehan moral dan tanggung jawab sosial. Jadi, keulamaan seseorang tidak dapat termanifestasi secara riil jika tidak dibarengi dengan penampakan sifat-sifat pribadi yang pantas mereka miliki. ${ }^{9}$ Sehingga penulis menyimpulkan bahwa seorang ulama memiliki tanggung jawab untuk berkompeten dalam ilmu-ilmu agama dan memiliki integritas kesalehan yang mampu memberikan keteduhan bagi masyarakat. Kesalehan diri merupakan poin penting yang harus dimiliki oleh seorang ulama, di samping integritas keilmuan yang mumpuni. Hal ini sesuai dengan predikatnya sebagai pewaris Nabi. Nabi tidak hanya kompeten dalam penguasaan ilmu agama karena hidup berdampingan dengan wahyu, namun Nabi juga merupakan panutan dalam pengimplementasian kesalehan moral yang hakiki.

Sebagai pemegang tongkat estafet dakwah Nabi, menurut M. Quraish Shihab, terdapat empat tugas utama yang harus dijalankan oleh ulama, yaitu menyampaikan ajaran-ajaran (Q.S. Al-Maidah: 67), menjelaskan ajaran-ajaran Allah (Q.S. Al-Nahl: 64),

\footnotetext{
${ }^{7}$ Nor Hasan, Studi Islam Kontemporer, (Pamekasan: STAIN Pamekasan, 2009), 24-33.

${ }^{8}$ Hasbiansyah, "Pendekatan Fenomenologi: Pengantar Praktik Penelitian dalam Ilmu Sosial dan $\begin{array}{llllll}\text { Komunikasi", Jurnal } & \text { Mediator, vol. } & \text { 9, no. }\end{array}$ ), 166 .

"Imam Hanafi dan Sofiandi, "Desekularisasi Ulama: Makna Ulama menurut Nurcholis Majid", Jurnal Madania, vol. 8, no.2, (Desember, 2018), 185-186.
} 
memutuskan perkara (Q.S. Al-Anbiya': 7) dan memberikan contoh penerapan hukum Allah (Q.S. Al-Baqarah: 213). ${ }^{10}$ Ulama tidak hanya sebagai figur yang menguasai keilmuan dan memahami ajaran-ajaran agama, tetapi juga sebagai penggerak, motivator dan dinamisator masyarakat ke arah pengembangan dan pembangunan umat. Perilaku dan ucapan ulama selalu menjadi teladan dan panutan. Penerimaan atau penolakan masyarakat terhadap suatu gagasan, konsep atau program, banyak dipengaruhi oleh ulama. ${ }^{11}$

Ulama memiliki peran yang signifikan dan strategis dalam Islam. Kedudukan ulama di dalam Al-Qur'an sangatlah mulia, dan Allah swt. menjadikan mereka sebagai makhluk yang berkedudukan tinggi, berperan sebagai pemimpin yang membawa petunjuk bagi umat Islam, dapat mencapai kedudukan al-akhyār (orang-orang yang penuh dengan kebaikan), serta derajat orang-orang yang bertakwa dengan ilmunya. ${ }^{12}$ Begitu istimewa posisi ulama di dalam Islam, maka tidak sulit untuk difahami kenapa ulama begitu dihormati dan memiliki pengaruh bagi umat Islam, tidak jarang, dogma tersebut membuat umat loyal terhadapnya. Dalam konfigurasi sosial kebudayaan ulama juga diangggap sebagai cultural broker (perantara budaya), ulamalah yang mampu memberikan filterasi dari realitas sosial kebudayaan dan politik yang berkembang di masyarakat. ${ }^{13}$

Dalam sejarah Islam, ulama memiliki posisi penting dalam perjalanan kekuasaan negara. Ulama merupakan satu-satunya figur yang diyakini memiliki wewenang dalam menafsirkan ajaran-ajaran Islam dan hukum-hukumnya. Meski, Ulama bukan sebuah jabatan tertentu yang diangkat secara resmi, namun jabatan yang disematkan adalah buah dari capaian keilmuannya. Dalam negara Islam masa lalu, ulama menjadi balance of power, penyeimbang kekuasaan pemerintah. Keberadaan ulama dalam negara menjadi pengontrol penguasa dalam menjalankan kekuasaannya. Penguasa dalam negara Islam wajib untuk menjalankan aturan Islam dalam setiap kebijakannya, ulama menjamin supaya penguasa tetap berada di jalan tersebut. Ulama memang tidak memiliki kekuatan untuk menjatuhkan penguasa. Namun posisi ulama sebagai panutan bagi masyarakat dan simbol pengikat bagi masyarakat menjadikan ulama mampu mengubah rezim yang berkuasa dengan cara mempengaruhi ketaatan masyarakat terhadap penguasa melalui fatwa dan ajaran-ajarannya. ${ }^{14}$

Menurut Graham E. Fuller, sulit sekali menemukan pemimpin agama Islam (ulama) yang mengarahkan tindakan-tindakan tentara Islam, seperti halnya seruan Paus

\footnotetext{
${ }^{10}$ Aar Arnawati, "Kedudukan dan Peran Ulama dalam Perspektif Al-Qur'an: Studi Komparatif Tafsir Al-Qur'ān al-Azìm dan Tafsir Fi Zilāl al-Qur'ān", Jurnal al-Fath, vol.11, no1, (Juni, 2017), 11.

${ }^{11}$ Imam Hanafi dan Sofiandi, “Desekularisasi Ulama...”, 187-188.

${ }^{12}$ Aar Arnawati, "Kedudukan dan Peran..., 2.

${ }^{13}$ Ade Wahidin, "Konsep Ulama Menurut Al-Qur'an", Al-Tadabbur: Jurnal Ilmu Al-Qur'an dan Tafsir, vol.1, no.1, (Juli, 2014), 7.

${ }^{14}$ Hasbi Aswar, "Pengaruh Ulama dalam Politik di Negara Muslim: Studi Kasus Arab Saudi", Jurnal Ilmu Sosial Indonesia, vol. 2, no.1, (Maret, 2015), 89.
} 
untuk memerangi umat muslim-merebut kembali tanah suci-dalam perang salib. Walaupun tidak dapat dipungkiri bahwa ulama tetap memberkati ekspedisi-ekspedisi militer Muslim. Ulama tidak mengilhaminya dan mengarahkannya. ${ }^{15}$ Dengan demikian, telah jelas bahwa urgensi keberadaan ulama dalam tubuh umat Islam sangat signifikan. Karena melalui kerja keras ulama, Islam dan firman Allah tetap tertanam dalam hati para pemeluknya.

Tidak jauh berbeda dengan kontribusi ulama pada pemerintahan dua dinasti sebelumnya. Di Indonesia, meski Islam merupakan agama yang datang belakangan dibandingkan dengan Hindu dan Budha. Tetapi, berkat kegigihan ulama-ulama nusantara (lokal), Islam dapat berkembang dengan baik dan mudah diterima oleh masyarakat. Hal tersebut tidak lepas dari kearifan para ulama dalam memperkenalkan Islam dalam bentuknya yang ramah dan rahmatan lil 'alamin. Tidak sedikit ulama yang kemudian memiliki posisi strategis dalam pemerintahan, dengan tetap mengemban tugas utama sebagai pemimpin dan panutan dalam beragama. Tugas utama para ulama ini adalah menjadi agen transfer ilmu keagamaan dan pembina akhlak masyarakat serta pemimpin keagamaan. Sampai saat ini, kedudukan ulama Idonesia tidak jauh berbeda. Meskipun tidak secara langsung memiliki kewenangan dalam pemerintahan, namun kapasitas mereka sebagai pemimpin agama masih diamini oleh mayoritas umat Muslim. Sehingga, dapat dianggap tepat sekali, pendapat Anuri Furqan Hadi yang menyebutkan bahwa Ulama pada perjalanan sejarahnya memberikan peran yang sangat penting dalam setiap segi kehidupan masyarakat. Ulama senantiasa dijadikan acuan dalam praktik peribadatan maupun praktik kehidupan sehari-hari. Dari urusan politik hingga urusan rumah tangga. ${ }^{16}$

Sakralitas mereka dalam pandangan masyarakat Muslim masih terjaga. Maka dari itu, tidak dapat dipungkiri bahwa bagi umat muslim Indonesia yang merupakan kelompok agama mayoritas dengan tingkat kereligiusan yang masih tinggi, Ulama dipandang sebagai sosok panutan yang memiliki sakralitas tersendiri. Setiap fatwanya adalah titah suci yang tanpa kompromi harus terimplementasi. Pandangan demikian merupakan pandangan sebagian besar umat Muslim Indonesia yang tergolong pada masyarakat muslim. Sehingga, ketaklidan masyarakat terhadap fatwa-fatwa ulama tidak dapat dihindari. Dalam wacana keberagamaan, ketaklidan terhadap sebuah ajaran keagamaan merupakan suatu fenomena yang niscaya karena tidak semua orang memiliki kompetensi tentang ajaran agama. Sehingga, umat muslim yang minim pengetahuan agama, memilih untuk mendengarkan fatwa ulama sebagai titah suci yang tidak jarang melahirkan fanatisme. Umat muslim saat ini berada pada posisi ittiba' atau taklid pada suatu tafsir hukum yang menurutnya disimpulkan berdasarkan jaring laba-laba. Meliputi

${ }^{15}$ Graham E. Fuller, Apa Jadinya Dunia Tanpa Islam: Sebuah Narasi Sejarah Alternatif, Terj. T. Hermay, (Mizan: Bandung, 2014), 143.

16 Anuri, Furqan Hadi, "Ulama dalam Pandangan Masyarakat Jakarta: Sebuah Pemaknaan Berdasarkan Ruang", Karsa, vol. 20, no.1, (2012), 109. 
keilmuan, sanad ilmu, corak ideologis, dan bahkan kepentingan sosial-politik-ekonomis yang diwarisi baik dari orang tua, guru maupun link-link virtual yang belum jelas. ${ }^{17}$

Menurut Abdillah, ulama memiliki kedudukan yang tinggi dan peran yang penting karena mereka merupakan pewaris para Nabi yang mempunyai tugas untuk: mendidik umat di bidang agama dan lainnya, melakukan kontrol terhadap masyarakat, memecahkan problem yang terjadi dalam masyarakat dan menjadi agen perubahan sosial. ${ }^{18}$ Dari pemaparan tersebut penulis dapat menyimpulkan bahwa ulama di dalam Islam sangat penting karena kalangan ulama berperan dalam pengontrolan perilaku masyarakat. Selain itu, ulama juga berperan dalam perumusan-perumusan ilmu agama yang dijadikan pedoman bagi masyarakat muslim dalam memahami agama. Khususnya di Indonesia, ulama merupakan gelar yang maemiliki sakralitas dalam pandangan masyarakat. Sakralitas tersebut dapat dilihat dari masih dari mayoritas umat muslim yang menjadikan ulama sebagai tempat mengambil fatwa.

Agama dan politik dapat diibaratkan dua sisi mata uang yang tidak dapat dipisahkan. Agama memberikan pedoman tentang nilai-nilai yang harus ditegakkan dalam undang-undang negara terutama dalam perkara Hak Asasi Manusia (HAM). Sedangkan politik merupakan alat yang untuk mendapatkan kekuasaan agar nilai-nilai agama tersebut dapat diterapkan. Hal tersebut bersumber dari paradigma bahwa hanya dengan memiliki otoritas atau kekuasaan suatu ide dapat diterapkan pada masyarakat secara luas. ${ }^{19}$ Maka, dalam hal ini, antara agama dan politik memiliki hubungan yang signifikan. Dengan paradigma inilah kemudian terdapat beberapa ulama yang memutuskan untuk memilih jalan politik untuk dapat menegakkan nilai-nilai Islam yang humanis dan ramah. Sebagai upaya penegakan amr ma'ruf nahi munkar. Tujuan mulia tesebut dikenal dengan istilah politik dakwah, yaitu pemanfaatan jalur politik untuk menyampaikan dakwah Islam atau sebuah strategi dalam melaksanakan dakwah lewat politik. Memahami Islam dari sisi politik adalah menyampaikan syiar agama melalui politik praktis. Dan berdakwah melalui jalur politik dinilai sebagai suatu kewajaran dan kecerdasan dalam memaksimalkan peluang dakwah. Hal tersebut sesuai dengan peran yang dijalankan oleh ulama yaitu sebagai penggerak, motivator dan dinamisator masyarakat ke arah pengembangan dan pembangunan umat. ${ }^{20}$

${ }^{17}$ Edi A.H. Iyubenu, Islam yang Menyenagkan: Etika Kemanusiaan sebagai Puncak Keimanan dan Keislaman, (Yogyakarta: IRCiSoD, 2017), 25.

${ }^{18}$ Ujang Mahadi, "Komunikasi Politik Kiai pada Kampanye Pemilu", Addin, vol. 9, no. 2 (Agustus, 2015), 234.

19 H.M. Ridwan Lubis, Sosiologi Agama: Memahami Perkemabangan Agama dalam Interaksi Sosial (Jakarta: Prenada Media Grup, 2015), 136.

${ }^{20}$ Bayu Mitra A. Kusuma, "Negosiasi Dakwah dan Politik Praktis: Membaca Orientasi Organisasi Sayap Keagamaan Islam Pada Partai Nasionalis", Al-Balagh: Jurnal Dakwah dan Komunikasi, vol. 2, no. 1, (Juni, 2017), 8-9. 
Oleh karena itu ulama memiliki peran signifikan bagi masyarakat karena dalam kenyataannya tatanan sosial-politik yang ada banyak yang tidak sejalan dengan ajaran agama. Karena itulah kiai atau ulama merasa perlu untuk terjun ke dalam dunia politik untuk mewujudkan kontrol kekuasaan yang sewenang-wenang dan menyimpang dari aturan moral, hukum, maupun aturan agama. Selain itu, konsep amar ma'ruf nahi munkar ini hendaknya juga dipahami dalam cakupan dan pengertian yang luas, yaitu mewujudkan perbaikan sistem pendidikan, penegakan supremasi hukum, meningkatkan kesejahteraan rakyat, dan memprioritaskan pembangunan bagi rakyat. ${ }^{21}$ Sejalan dengan pendapat ulin Nuha, Al-Faruqi mengatakan bahwa ulama adalah simbol dari etika dan moralitas politik. Keterlibatan ulama dalam dunia politik diharapkan mampu memberi sumbangan besar bagi terciptanya bangunan struktur politik yang bermoral. Moral yang betul-betul hidup dan menjadikan landasan politik dan bukan sekedar slogan politik. ${ }^{22}$ Menurut Amin Rais, tujuan dari politik bukan hanya untuk kekuasaan, tetapi untuk melakukan pengabdian kepada Allah dengan menggunakan media politik. Suatu tindakan politik adalah baik jika berguna bagi seluruh rakyat sesuai dengan ajaran Islam yang rahmatan lil 'alamin. Hal senada disampaikan pula oleh Ketua Umum PP Muhammadiyah, M. Dien Syamsuddin yang mengatakan bahwa politik harus dipahami sebagai faktor instrumental untuk kontekstualisasi cita-cita sosial Islam ke dalam cita-cita nasional. Sedangkan Mahdi Bahar mengemukakan bahwa kekuasaan yang ideal adalah kekuasaan yang dapat meneguhkan agama yang diridhai Tuhan untuk kehidupan manusia. ${ }^{23}$ Thohari mengatakan bahwa seorang muslim yang memilih politik sebagai lapangan perjuanagn harus menegakkan moralitas Islam. Pertama, ia tidak boleh larut dalam opini publik yang sekuler yang memandang bahwa dalam politik orang boleh bertindak kotor. Kedua, seorang muslim justru harus berdakwah untuk menegakkan akhlak Islam dalam politik. Jadi, sesorang yang memilih lapangan perjuangannya dengan memilih politik dipersilahkan dan tidak haram. Sepanjang mengedepankan nilai-nilai Islam yang santun dan bertujuan untuk mewujudkan kemaslahatan masyarakat. Bukan untuk kepentingan atau memperkaya diri. Dengan masuknya ulama dalam dunia politik diharapkan image politik yang telah terlanjur negatif di mata masyarakat dapat terkikis. ${ }^{24}$

Namun, apabila mengaca pada dunia perpolitikan Indonesia hari ini, ulama yang diharapkan kontribusinya dalam memperbaiki sistem politik Indonesia yang tidak lagi menggambarkan rasa humanis karena telah dibutakan oleh bayang-bayang kekuasaan, malah ikut larut dalam euforia politik praktis. Pada kontestasi politik tahun 2019,

${ }^{21}$ Ulin Nuha, "Peran Politik Kiai Dalam Proses Politik di Partai Politik (Studi Kasus Peran KH. A. Haris Shodaqoh Di Partai Persatuan Pembangunan", Politika: Jurnal Ilmu Politik, vol. 3, no. 2, (Mei. 2013), 34 .

${ }^{22}$ Ujang Mahadi, "Komunikasi Politik Kiai pada Kampanye Pemilu", Jurnal Addin, vol. 9, no. 2, (Mei, 2015), 231.

${ }^{23}$ Ahmad Asroni dkk, "Dakwah dan Politik: Menakar Kontribusi Organisasi Islam Sayap Partai Politik Bagi Masyarakat Muslim Yogyakarta", Jurnal Dakwah, vol. 14, no. 1 (Mei, 2013), 23.

${ }^{24}$ Ujang Mahadi, "Komunikasi Politik Kiai...", 242. 
terdapat dua kandidat presiden dan wakil presiden, yaitu Joko Widodo yang didampingi oleh KH. Ma'ruf Amin dan Probowo Subianto dengan Sandiaga Solahuddin Uno. Pada kubu pertahanan, Jokowi Dodo di dampingi oleh KH. Ma'ruf Amin yang merupakan seorang ulama yang memiliki kapasitas yang mumpuni dalam bidang agama. Terbukti dengan kedudukannya di MUI dan NU. Pemilihan KH. Ma'ruf Amin, oleh beberapa pengamat dipandang sebagai langkah meredam isu SARA yang dialamatkan kepada presiden Joko Widodo, ${ }^{25}$ setelah terjadinya kasus penistaan agama yang dilakukan oleh Basuki Cahya Purnama (Ahok) yang merupakan rekan politik Jokowi dan mantan Gubernur DKI Jakarta.

Selain itu, perebutan dukungan ulama menjadi topik yang tidak dapat dihindari pada kontestasi politik kali ini. Masing-masing kubu mengklaim mendapat dukungan ulama. Kesadaran akan kekuatan suara umat muslim sebagai pemeluk agama mayoritas yang mengantarkan masing-masing kubu merasa urgen mendapatkan dukungan ulama. Ditambah latar belakang sosial masyarakat Indonesia yang menjadikan ulama sebagai acuan dalam memutuskan setiap perkara dalama kehidupannya, tidak terkecuali dalam penentuan pilihan politik. Berdasarkan survey yang dilakukan oleh Lingkaran Survey Indonesia (LSI), Deni J. A. Ketika menjelaskan tentang acuan yang dipertimbangkan dalam menentukan pilihan politik, 51,7\% responden menyatakan acuan mereka dalam menentukan pilihan politik adalah himbauan dari tokoh agama, salah satunya ulama. ${ }^{26}$ Kiai dan tokoh pesantren merupakan salah satu basis dukungan yang diharapkan oleh partai pilitik. Semakin banyak kiai dan tokoh pesantren yang menjalin relasi dan tergabung, maka pengikut setia kiai dan santrinya akan mengikuti apa yang didakwahkannya. ${ }^{27}$ Kyai masih ditempatkan sebagai sumber "fatwa" terakhir ketika masyarakat berada di simpang jalan di antara pilihan-pilihan politik yang membingungkan. ${ }^{28}$

Dalam hal ini, Islam sebagai agama yang paling besar penganutnya, tentu saja akan menjadi sasaran empuk berbagai parpol dan para politisi di Indonesia. Umat Islam merupakan aset politik strategis. Siapa yag berhasil mengambil hati mayoritas umat Mmuslim, sudah dapat dipastikan akan memegang tampuk kekuasaan. Sehingga Islam rentan dipolitisasi. Mengutip dari pendapat Azyumardi Azra, bahwa perebutan pemilih Islam oleh partai politik merupakan hal yang wajar dan strategis bagi partai politik. Namun, ketika agama hanya dijadikan sebagai alat untuk mendapatkan kekuasaan maka agama akan sangat rentan terhadap manipulasi. ${ }^{29}$

${ }^{25}$ Deasy Simanjuntak, "Indonesia: Politik Identitas...."

${ }^{26}$ Habib Bahar Terjerat Hate Speech?, dalam https://www.pinterpolitik.com/habib-bahar-terjerathate-speech, diakses pada tanggal 03 Januari 2019.

${ }^{27}$ Bayu Mitra A. Kusuma, "Negosiasi Dakwah dan Politik Praktis: Membaca Orientasi Organisasi Sayap Keagamaan Islam Pada Partai Nasionalis", Al-Balagh: Jurnal Dakwah dan Komunikasi, vol. 2, no. 1, (Juni, 2017), 19.

${ }^{28}$ Ibid.

${ }^{29}$ Ahmad Asroni, dkk, “Dakwah dan Politik: Menakar..., 32. 
Ujaran kebencian yang dilakukan oleh salah satu ulama Indonesia terhadap salah satu paslon dan berakhir pada penahanan terhadap ulama tersebut telah menimbulkan isu "Kriminalisasi Ulama". Hal tersebut merupakan salah satu contoh konkret bagaimana agama dijadikan alat untuk mendapatkan kekuasaan. Sehingga, agama menjadi isu sensitif di tengah-tengah kontestasi politik.

Penggiringan opini publik melalui dakwah merupakan fenomena yang dikenal dengan istilah politik dakwah. Berbanding terbalik dengan dakwah politik yang menjadikan politik sebagai alat dakwah-menegakkan amar ma'ruf nahi mungkar. "Dakwah politik dipahami sebagai upaya memanfaatkan daya tarik aktivitas dakwah untuk meraih kepentingan politik atau dakwah (ajakan) untuk tujuan politik. Praktik politik dakwah ini memunculkan politisasi dakwah yang turut menyeret Islam dalam konflik kepentingan elit. Dengan demikian, agama hanya menjadi kendaraan politik. Melalui aktivitas dakwah, cara pandang dan pemikiran masyarakat nuslim diarahkan untuk sejalan dengan kepentingan politisi. Sehingga, aktivitas dakwah dijadikan sebagai media strategis bagi politisi untuk menghegemoni pemikiran umat atau masyarakat awam terkait pilihan politik". ${ }^{30}$

Berdasarkan data yang diperoleh dari Dewan Masjid Indonesia (DMI) ditemukan bahwa 6,98 persen materi ceramah yang disampaikan para ulama atau penceramah di masjid berisikan ujaran kebencian. ${ }^{31}$ Maka, tidak dapat dipungkiri bahwa pada akhirnya terjadi pembentukan stigma kita dan mereka/saya dan kamu. Walaupun, antara dua belah pihak sama-sama dalam rumpun agama yang sama. Agama hanya dijadikan tunggangan kepentingan beberapa elit untuk mendapatkan kekuasaan. Dalam hal ini ulama berperan menjadi objek dan salah satu aktor utama dalam permainan politik identitas yang berlebihan. Agama adalah bagian dari identitas yang seringkali menjadi alat utama dalam menjalankan politik identitas. Di Indonesia, politik identitas sangat kental dengan nuansa etnisitas, agama, ideologi, dan kepentingan-kepentingan lokal yang diwarnai oleh para aktor seperti elit. Berbicara tentang politik identitas adalah tindakan politis untuk mengedepankan kepentingan-kepentingan dari anggota-anggota suatu kelompok karena memiliki kesamaan identitas atau karakteristik, baik berbasiskan pada ras, etnisitas, jender, atau keagamaan. Menguatnya Politik identitas ini dapat kita lihat contoh-contohnya di banyak daerah, yaitu adanya gerakan gerakan serba kedaerahan, keagamaan, kesukuan, sampai gerakan cara berpakaian yang melambangkan kedaerahan dan keagamaan tertentu. Pemaknaan bahwa politik identitas sebagai sumber dan sarana politik dalam pertarungan perebutan kekuasaan politik sangat dimungkinkan dan kian mengemuka dalam praktek politik sehari-hari, karena itu para ilmuwan yang bergelut dalam wacana politik identitas berusaha sekuat mungkin untuk mencoba menafsirkan

\footnotetext{
${ }^{30}$ Bayu Mitra A. Kusuma, "Negosiasi Dakwah dan Politik Praktis: Membaca Orientasi Organisasi Sayap Keagamaan Islam Pada Partai Nasionalis", 9-10.

${ }^{31}$ Habib Bahar Terjerat Hate Speech?, dalam https://www.pinterpolitik.com/habib-bahar-terjerathate-speech, diakses pada tanggal 03 Januari 2019.
} 
kembali dalam logika yang sangat sederhana dan lebih operasional. ${ }^{32}$ Sebenarnya Donald L Morowitz salah satu pakar politik dari universitas Duke telah mendefinisikan politik identitas sebagai pemberian garis yang sangat tegas untuk menentukan siapa yang akan disertakan dan siapa yang akan ditolak..33

"Politik identitas merujuk pada berbagai bentuk mobilisasi politik atas dasar identitas kolektif yang sebelumnya seringkali disembunyikan (hidden), ditekan (suppressed) atau diabaikan (neglected), baik oleh kelompo dominan yang terdapat dalam sistem demokrasi liberal atau oleh agenda politik kewarganegaraan yang diusung untuk dan atas nama demokrasi yang lebih progresif". ${ }^{34}$ Pada dasarnya, dalam dunia Islam, khususnya Indonesia, politik identitas merupakan suatu hal yang lumrah. Misalnya pada masa kolonial belanda terdapat usaha pihak kolonial untuk menjauhkan para intelektual pribumi dari rasa kebangsaan dan ke-Islamannya melalui upaya asosiasi pendidikan. Namun, upaya tersebut gagal karena kesadaran agama dan kebangsaan itu muncul lebih besar bersama semangat Islam yang begitu kuat, rasa ukhwah slamiyah dan rasa agama yang tinggi dari agama lain membuat umat Islam lebih merapatkan barisan dan Islam menjadi pemersatu dalam menghadapi kaum penjajah. Namun, identitas Islam yang dimiliki oleh umat muslim, kini tengah manjadi bahan politisasi yang memicu terjadinya konflik di tengah masyarakat. Padahal salah satu tujuan politik adalah melembagakan penyelesaian konflik agar konflik itu tidak melebar menjadi anarkisme dan kekerasan. Pada kenyataannya politik justru menyalurkan konflik ke dalam prosedur, aturan dan mekanisme membangun kompromi dan konsensus antar aktor dan pemaina-pemain politik. ${ }^{35}$

Hemat penulis, politik identitas yang dimainkan pada pilpres tahun ini, tidak lagi mencerminkan perjuangan untuk mendapatkan keadilan dari kelompok dominan. Karena pemain politik identitas dimainkan oleh kalangan umat muslim yang notabene kelompok agama mayoritas di Indonesia. Sehingga, dijadikannya umat muslimkhususnya ulama-sebagai alat meligitimasi kepentingan kubu politik akan berdampak pada terkotak-kotaknya masyarakat. Politik yang berkenaan dengan isu SARA (suku, agama, ras, dan antar golongan) berpeluang besar dalam memecah belah bangsa. Politik agama yang dilakukan oleh golongan tertentu akan merugikan pihak oposisi karena masyarakat teralih fokusnya terhadap identitas-identitas para calon bukan melihat pada kualitas dan program para kandidat. Hal semacam ini tentu tidak fair bagi suku atau golongan minoritas yang merasa terdiskriminasi. Politisasi agama dalam menjatuhkan

${ }^{32}$ Fitri Ramdhani Harahap, Politik Identitas Berbasis Agama. Proceeding Konferensi Nasional Sosiologi III Transformasi Demokrasi Indonesia Menuju Perubahan Yang Bermakna Yogyakarta, 20-22 Mei 2014, 511-512.

${ }^{33}$ Zahrotunnimah, "Sejarah Politik Identitas dan Nasionalisme Di Indonesia", Jurnal Al-'Adalah, vol. 2, no. 10, (2018), 93.

${ }^{34}$ Purwanto, "Politik Identitas dan Resolusi Konflik Transformatif", Review Politik, vol. 6, No. 1 (Juni, 2015), 67.

${ }^{35}$ Ujang Mahadi, “Komunikasi Politik Kiai...., 234-235. 
lawan politik sesungguhnya bertentangan dengan peraturan perundang-undangan. Hal ini sering kali dipakai karena dianggap paling mudah dan cepat (politik praktis) dalam mengambil simpati masyarakat. ${ }^{36}$

Masuknya ulama ke dalam politik, bukan suatu perkara yang terlarang. Tetapi, suatu perkara yang diharapkan dapat membawa memperbaikan citra politik yang telah terlanjur dipandang negatif olah masyarakat. Selain itu, penggunaan politik sebagai alat untuk berdakwah-menanamkan nilai-nilai Islam-kepada masyarakat dipandang sah-sah saja. Sebagaiman firman Allah swt. pada Q.S. Ali ‘Imran (3): 104. Menurut Sayyid Qutub dalam tafsirnya, haruslah ada orang atau kekuasaan yang menyeru kepada kebajikan, menyuruh kepada yang ma'ruf dan mencegah pada yang munkar. Dalam hal ini, ulama merupakan sosok yang dianggap mampu untuk mewujudkan penegakan amar ma'ruf nahi munkar. Karena dengan pengetahuan agama yang dimiliki dianggap mampu untuk memperbaiki tatanan politik yang terlanjur diangga tidak baik, melalui jalan politik dakwah. Apabila dakwah dapat dilakukan oleh orang yang tidak memiliki kekuasaan, maka "perintah dan larangan" itu tidak dapat dilakukan kecuali oleh orang yang memiliki kekuasaan. ${ }^{37}$ Maka dari itu, tidak dapat dipungkiri bahwa jalan dakwah yang dipilih oleh ulama berangkat dari paradigma, bahwa dengan kekuasaan penerapan nilanilai moral Islam-amar ma'ruf nahi munkar-dapat terwujud.

Kemudian firman Allah lainnya pada Q.S. Ali 'Imran (3): 110, dikatakan sebagai khair umah. Umat yang tergolong pada umat yang terbaik adalah umat Nabi Muhammad dari generasi ke generasi. Hal ini karena umat Islam terus menerus tanpa bosan menyuruh kepada yang ma'ruf-nilai-nilai baik dalam masyarakat yang sesuai dengan nilai-nilai Ilahi-dan mencegah pada yang munkar-bertentangan dengan nilai-nilai luhuryang timbul dari keimana yang benar yaitu percaya dan mengamalkan tuntunan Allah dan Rasul-Nya. Di samping itu, apabila ahl al-kitab beriman seperti imannya orang mukmin maka mereka mendapat kebajikan dan dapat menjadi sebaik-baik umat pula. ${ }^{38}$ Ali Nurdin mengatakan bahwa: "Khairu ummah adalah bentuk ideal masyarakat Islam yang identitasnya adalah integritas keimanan, komitmen dengan berkontribusi positif kepada kemanusiaan secara universal dan loyalitas kebenaran dengan aksi amar ma'ruf nahi munkar sebagaimana dideklarasikan oleh Allah dalam Q.S. Ali Imran 104 dan Ali Imran 110". ${ }^{39}$

Untuk mewujudkan lahirnya khairu ummah, ulama sebagai simbol kebaikan dalam tubuh umat Islam, harus menjadi teladan yang baik bagi masyarakat muslim. Dengan begitu, umat Islam memiliki gambaran tentang kebaikan hakiki yang harus mereka

${ }^{36}$ Budi Kurniawan. "Politisasi Agama di Tahun Politik: Politik Pasca-Kebenaran di Indonesia dan Ancaman bagi Demokrasi", Jurnal Sosiologi Agama, vol. 12, no. 1 (2018), 135.

${ }^{77}$ Sayyid Qutb, Tafsir Fi Dzilalil Quran, vol. 1, (Jakata: Gema Insani Press, 2003), 148.

${ }^{38}$ M. Quraish Shihab, Tafsir al-Misbah: Pesan, Kesan, dan Keserasian al-Qur'an, (Jakarta: Lentera Hati, 2012), 221-222.

${ }^{39}$ Ali Nurdin, Qur'anic Society: Menelusuri Konsep Masyarakat Ideal dalam Al-Quran, (Jakarta: Penerbit Erlangga, 2006), 115. 
lakukan. Dalam keikutsertaan ulama dalam poltik akan semakin mempermudah kelahiran khairu ummah. Maka, Penegakan amar ma'ruf nahi maungkar sebagai tujuan dari ikut sertanya ulama dalam politik, sesuai dengan penggunaan kata politik itu sendiri di dalam Al-Qur'an. kata politik dalam bahasa Arab biasanya diterjemahkan dengan kata siyasah yang terambil dari kata sasa-yasusu. Artinya mengemudi, mengendalikan, mengatur dan sebagainya. Namun, didalam Al-Qur'an kata politik tidak ditemukan dalam bentuk kata tersebut. politik dalam Al-Qur'an, secara sepintas ditemukan pada ayat-ayat yang berakar kata hukm. Makna awal dari kata ini adalah menghalangi atau melarang dalam rangka perbaikan. ${ }^{40}$ Dalam penegakan amar ma'ruf nahi munkar harus dilakukan dengan cara yang adil. Allah berfirman dalam surat al-Nisa': 58, "Dan apabila kamu berhukum (menjatuhkan putusan) di antara manusia, maka hendaklah kamu memutuskan dengan adil."

Sehingga, pemilihan politik sebagai alat menanamkan nilai-nilai Islam oleh ulama, tidak bertentangan dengan Al-Qur'an selama keadilan tetap dipegang teguh. Namun, fenomena perebutan dukungan ulama antar dua kubu calon presiden-wakil presiden, hanya menjadi alat legitimasi bahwa kubu yang mendapat dukungan ulama lebih banyak adalah kubu yang lebih Islam dibandingkan lainnya. Sehingga, umat Islam akar rumput akan tergiring untuk memilih kubu yang dominan. Padahal dalam Al-Qur'an telah dijelaskan bahwa kedudukan semua manusia itu sama, yang membedakannya adalah tingkat ketakwaannya. Sebagaimana yang tergambar dalam surah al-Hujarat ayat 13, "Hai manusia, sesungguhnya Kami menciptakan kamu dari seorang laiki-laki dan seorang perempuan dan menjadikan kamu berbangsa-bangsa dan bersuku-suku supaya kamu saling kenal-mengenal. Sesungguhnya orang yang paing muia di sisi Allah adalah orang yang paling bertakwa di antara kamu. Sesungguhnya Allah Maha mengetahui lagi Maha mengenal."

Menurut Quraish Shihab, semakin kuat pengenalan satu pihak dengan pihak yang lain, maka semakin terbuka peluang untuk saling memberi manfaat demi mewujudkan kedamaian dan kesejahteraan hidup dunia dan akhirat. Namun, tidak dapat dipungkiri bahwa perbedaan ras, bahasa, negara dan lainnya-pilihan politik-membuat orang sulit berinteraksi. ${ }^{41}$ Perbedaan identitas dalam ayat tersebut merupakan sunnatullah. Pembinaan yang baik terhadap perbedaan identitas, dapat menumbuhkan harmoni dalam kehidupan umat manusia. Jadi, perbedaan identitas tidak seharusnya menjadi kendala bagi hubungan antar manusia. Dalam hal ini, politik identitas bukan suatu fenomena politik yang harus dikhawatirkan. Karena tujuan utama dari politik ini adalah tercapainya keadilan baik di bidang sosial, politik dan ekonomi bagi suatu kelompok identitas.

Namun, perkembangan politik identitas pada era kontestasi politik saat ini, tidak lagi menjadikan keadilan sebagai tujuan utamanya. Walaupun, secara redaksi penggunaan istilah politik identitas tetap mengelu-elukan kesetaraan dalam bentuk

\footnotetext{
${ }^{40}$ M., Quraish Shihab, Tafsir al-Misbah..., 409-410.

${ }^{41}$ Ibid., 262.
} 
keadilan di berbagai bidang. Politik identitas yang dimainkan pada euforia kontestasi politik kali ini, lebih dominan pada cara memperjuangkan sebuah kekuasaan. Dengan mengenyampingkan etika dan penghargaan terhadap sesama manusia. Ujaran kebencian dan pelecehan yang dialamatkan oleh salah satu ulama Indonesia kepada salah satu paslon merupakan bukti konkret tumbuhnya politik identitas di tengah-tengah masyarakat khususnya ulama. Dakwah yang semestinya mengutamakan kesejukan dan ketentraman batin, malah menjadi media untuk menjatuhkan orang lain. Pada hal di Q.S. Ali Imran (3): 159 telah jelas disebutkan,

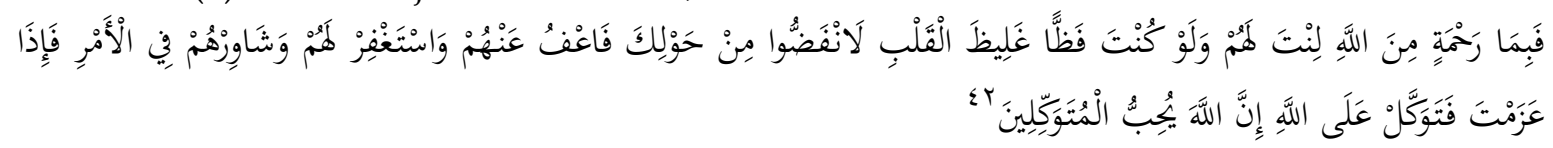

"Maka disebabkan rahmat Allah-lah kamu berlaku lemah lembut terhadap mereka. Sekiranya kamu bersikap keras lagi berhati kasar, tentulah, tentulah mereka menjauhkan diri dari sekelilingmu. Katrena itu, maafkanlah mereka, dan bermusyawarahlah dengan mereka dalam urusan itu. Kemudian apabila kamu telah membulatkan tekad, maka bertawakallah kepada Allah. Sesungguhnya Allah menyukai orang-orang yang bertawakal kepada-Nya."

Dalam tafsir al-Maraghi, dijelaskan bahwa Rasulullah selalu berpegang teguh pada musyawarah selama hidupnya dalam menghadapi semua persoalan. Menurutnya, manfaat dari musyawarah adalah timbulnya keterbukaan, sehingga keikhlasan dan kecintaan seseorang terhadap kepentingan umum bukan kepentingan pribadi dan kelompok, diketahui kelebihan dan kelemahan dari suatu pandangan, pengujian opini dan timbulnya saling pengertian di antara teman diskusi (Musthafa, t.th: 196). ${ }^{43}$ Sedangkan menurut Buya Hamka, ayat tersebut menggambarkan keteladanan Nabi Muhammad sebagai seorang pemimpin yang lemah lembut sehingga dapat membina umat Islam dengan baik. Karena pemimpin yang kasar, keras hati, dan kaku sikapnya adalah pemimpin yang tidak sesuai dengan Al-Qur'an.44 Menurut Quraish Shihab, musyawarah harus di dasari dengan sikap lemah lembut dan pemaaf serta dibekali dengan akal yang sehat. Dengan hal itu akan timbul Saling pengertian antar sesama anggota musyawarah. ${ }^{45}$ Ayat ini menjelaskan betapa pentingnya berperilaku lemah lembut dan bermusyawarah. Dengan perilaku tersebut seseorang dapat membina $u k h w a h$ baik dengan sesama manusia.

Bentuk jamak dari kiai (alim) adalah alimun dan ulama. Dalam Al-Qur'an kata alim yang berjamak dari alimun diartikan sebagai orang yang punya kelebihan ilmu dan kadar kecerdasan yang dengan itu dia mampu mengeluarkan ayat-ayat Allah dan lebih menonjolkan penampilan keilmuan sebagai orang yang alim. Sedangkan yang berjamak ulama adalah orang yang dengan keyakinannya merasa malu untuk berbuat yang

\footnotetext{
42 Al-Qur'an, Ali Imron (3): 159.

${ }^{43}$ Ibid.

${ }^{44}$ Hamka, Tafsir al-Azhar, (Jakarta: Pustaka Panji Mas, 1983), 130.

${ }^{45}$ M., Quraish Shihab, Tafsir al-Misbah..., 313.
} 
membias dari rasa kehambaan. Dalam hal ini tidak harus ilmu agama. ${ }^{46}$ Kata ulama di dalam Al-Qur'an memiliki beberapa sinonim. Di antaranya, kata al-'alimun (Q.S. al'Ankabut: 43), ulu al-albab (Q.S. Ali Imran: 190), ulu al-abshar (Q.S. Ali Imran: 13), ulu alnuha (Q.S. Thaha: 54), ulu al-ilm (Q.S. Ali Imran: 18) dan utu al-ilm (Q.S. al-Rum: 56). ${ }^{47}$ kata-kata tersebut bermakna orang yang berakal, berilmu, memiliki mata hati. Jadi, dari makna kata 'alim dan kata yang bersinonim dengan kata ulama, disimpulkan bahwa ulama adalah orang-orang yang memiliki ilmu dan berakal. Selain itu, seseorang yag dikatakan sebagai ulama adalah mereka yang menggunakan mata hati mereka dalam memaknai ilmu pengetahuan yang dimiliki. Allah berfirman dalam Q.S. Fathir: 28,

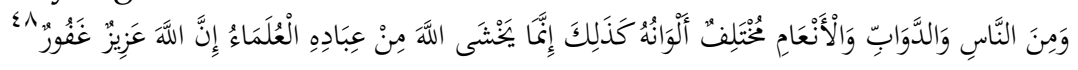

"Sesungguhnya yang takut kepada Allah di anatar hamba-hamab-Nya, hanyalah ulama. Sesungguhnya Allah Maha perkasa lagi Maha pengampun."

Sebelum menyinggung kata ulama, ayat di atas menjelaskan terlebih dahulu tentang kebesaran kekuasaan Allah dalam menciptakan berbagai macam makhluk yang merupakan suatu keniscayaan dan sunnatullah. Begitu pula perbedaan pendapat yang muncul di antara para pakar ilmu ilmiah-baik ilmu alam maupun ilmu sosial-dan tanggapan manusia dalam membenarkan keterangan yang terdapat dalam kitab-kitab suci, penafsirannya dan para Nabi. Setelah keterangan tersebut, baru dikatakan bahwa hanya ulama yang merasakan khasyat di dalam dirinya. Redaksi ayat tersebut berimplikasi pada pemaknaan bahwa seseorang dapat dikatakan sebagai ulama apabila memiliki pengetahuan dan penghayatan tentang keberagaman ciptaan Allah, yang kemudian melahirkan rasa khasyat (takut) dalam dirinya. Sehingga, Khasyat merupakan syarat mutlak bagi seseorang yang dapat dianggap ulama. Orang yang tidak memiliki khasyat di dalam hatinya tidak dapat dikatakan sebagai ulama. ${ }^{49}$ Hakikat Khasyat menurut Sa'id bin Jubair rahimahullah, sebagaimana yang dikutip oleh Ade Wahidin, adalah suatu perasaan yang menghalangi jiwa seseorang untuk bermaksiat kepada Allah. Konsekuensi dari rasa takut tesebut adalah lahirnya sikap kehati-hatian dalam diri seseorang. Sikap untuk senantiasa menjaga perilakunya baik terhadap Tuhannya, sesama manusia dan kepada alam. Dengan kata lain, rasa khasyat yang dimilki oleh seorang ulama melahirkan rasa kesadaran bahwa di setiap tindakannya terdapat pengawasan Allah SWT. ${ }^{50}$

Ulama menurut adalah mereka yang memiliki khasya (rasa takut) kepada Allah, karena pengetahuan mereka tentang kebesaran dan kekuasaan Allah, sehingga mereka selalu mentaati dan menjauhkan diri dari maksiat. Ulama terbagi menjadi tiga, yaitu 'alim billah wa bi amrillah, 'alim billah tapi tidak 'alim bi amrillah dan 'alim bi amrillah tapi tidak

\footnotetext{
${ }^{46}$ Abdurrahman, "Fenomena Kiai dalam ...., 26

${ }^{47}$ Ade Wahidin, "Konsep Ulama Menurut Al-Qur'an", 42-44.

${ }^{48}$ Al-Qur'an, Fatir (35): 28.

${ }^{49}$ M., Quraish Shihab, Tafsir al-Misbah..., 62.

${ }^{50}$ Ade Wahidin, “Konsep Ulama Menurut Al-Qur'an”, 45.
} 
'alim billah. Kategori ulama yang pertama adalah ulama yang memiliki khasya kepada Allah dan mengerti tentang hukum hudud dan faraid. Ulama dalam kategori kedua adalah ulama yang memiliki rasa takut kepada Allah, tapi tidak mengerti perkara hudud dan faraid. Sedangkan ketegori ketiga merupakan ulama yang mengerti tentang perkara hudud dan faraid tapi tidak memiliki khasya kepada Allah. Ulama merupakan pewaris para Nabi. Sehingga, mereka adalah orang-orang yang diikuti langkah dan perbuatannya, dan orang yang diambil pendapat dan persetujuannya. Ilmu yang dimiliki oleh ulama akan mengangkat derajatnya, sebagimana firman Allah dalam Q.S. Mujadalah: 11. Maka dari itu, seseorang wajib menjaga hak-hak para ulama baik ketika masih hidup maupun sudah meninggal. ${ }^{51}$

Menurut Buya Hamka, ulama yang banyak sekarang adalah ulama golongan ketiga. Pengetahuannya tentang agama hanya menjadi pengetahuan tanpa penghayatan. Sehingga, pengetahuannya hanya difungsikan untuk memainkan ayat demi memenuhi kebutuhan orang-orang yang bertanya. Kemudian Hamka menambahkan bahwa ulama bukanlah seseorang yang hanya mengkaji hukum-hukum agama atau orang yang memakai atribut keagamaan (sorban atau gamis). Bukan seseorang yang pengetahuannya tentang agama terbatas, tetapi telah berani memberikan pernyataan-pernyataan yang kadang tidak sesuai dengan syariat Islam-bid'ah dipandang sunah-dan mudah mengkafirkan orang lain yang tidak sepaham. Menganggap dirinya dan kelompoknya yang paling benar. ${ }^{52}$

Maka, tidak dibenarkan apabila seseorang yang dianggap ulama, mudah melakukan cacian dan mengolok-olok orang yang dianggapnya lawan (tidak sejalan) dengan dirinya. Sebagaimana firman Allah di Q.S. Al-Hujurat: 11:

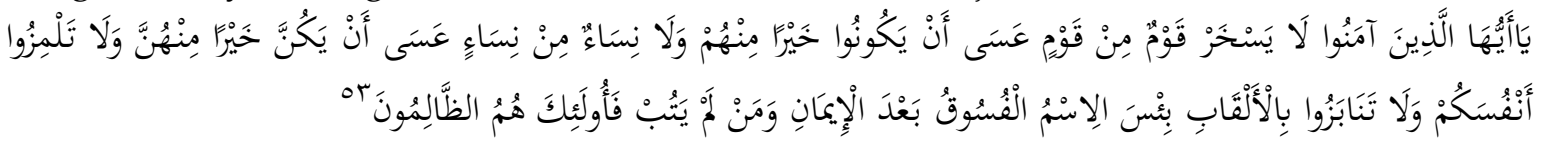

"Hai orang-orang yang beriman janganlah suatu kaum mengolok-olok kaum yang lain, boleh jadi mereka lebih baik dari mereka, dan jangan pula wanita-wanita terhadap wanita-wanita lain, boleh jadi mereka lebih baik dari mereka dan janganlah kamu mengejek diri kamu sendiri dan janganlah kamu panggil-memanggil dengan gelar-gelar buruk. Seburuk-buruk panggilan ialah kefasikan sesudah iman dan barang siapa yang tidak bertaubat, maka mereka itulah orang-orang yang zalim."

Keterangan untuk tidak mengolok-olok orang lain dan memanggilnya dengan panggilan yang tidak baik merupakan suatu keterangan yang bersifat larangan kepada orang-orang yang beriman-termasuk di dalamnya ulama yang merupakan orang-orang yang memiliki pengetahuan dan penghayatan terhadap kekuasaan Allah-karena orang

\footnotetext{
${ }^{51}$ Aar Arnawati, "Kedudukan dan Peran....", 6.

52 Hamka, Tafsir al-Azhar, (Jakarta: Pustaka Panji Mas, 1983), 247.

${ }^{53}$ Al-Qur'an, Al-Hujurat (49): 11.
} 
yang diolok-olok atau dipanggil dengan panggilan buruk, memiliki tempat yang lebih baik di mata Allah. Kata yaskhar (memperolok-olok) dimaknai oleh Quraish Shihab sebagai menyebut kekurangan pihak lain dengan tujuan menertawakan orang yang diperolok, baik dengan ucapan, sikap maupun perbuatan. Sedangkan talmizu sebagaimana pendapat yang dikutip Ibn 'Asyur, yaitu "Ejekan yang dihadapkan pada seseorang dengan, baik dengan isyarat, bibit, tangan atau kata-kata yang dipahami sebagai ejekan" ${ }^{54}$ Maka, penghinaan dalam bentuk apapun berdasarkan ayat di atas tidak dapat dibenarkan. Karena seharusnya seorang ulama adalah orang yang dengan rasa takut dalam dirinya, senantiasa mampu untuk menjaga lisannya dari perkataan yang dapat menjatuhkan atau melecehkan orang lain. Kemudian ayat selanjutnya menerangkan,

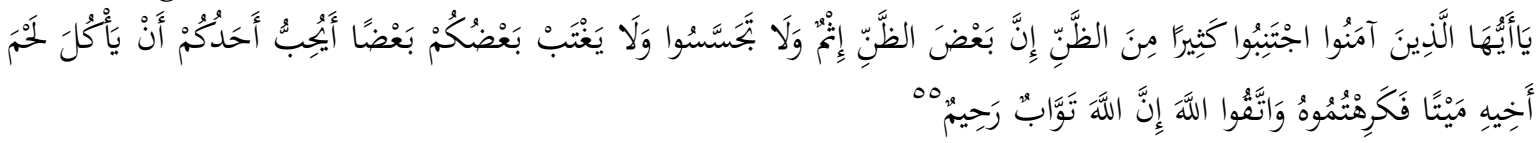

"Hai orang-orang yang beriman, jauhilah banyak dari dugaan, sesungguhnya sebagian dugaan adalah dosa dan janganlah kamu mencari-cari kesalahan orang lain serta jangan sebagian kamu menggunjing sebagian yanag lain. Sukakah salah seorang di antara kamu memakan daging saudaranya yang sudah mati? Maka kamu telah jijik kepadanya dan bertawakalah kepada Allah. Sesungguhnya Allah Maha Penerima taubat lagi Maha Penyayang" Q.S. al-Hujarat: 12.

Orang-orang yang beriman-termasuk ulama-diperintahkan untuk menjauhi pasangka (dugaan) dan mencari-cari kesalahan orang lain dan menggungjingkannya. Ketiga hal ini, disatukan karena merupakan satu kesatuan. Prasangka dapat melahirkan keinginan untuk mencari-cari kesalahan orang lain, setelah itu ,menggunjingkannya. Padahal menggunjing adalah suatu perbutan yang diumpamakan memakan bangkai saudaranya. Dugaan dapat dibenarkan apabila menyangkut hukum-hukum agama, karena hkum-hukum agama sifatnya dzanny (dugaan). Sedangkan dugaan yang sifatnya dosa adalah dugaan yang tidak berdasar, yang biasanya ditujukan kepada pihak lain. ${ }^{56}$ Tidak selayaknya kejelekan yang dimiliki oleh seseorang yang dianggpa lawan politik diumbar di depan umum. Bahkan dengan perangai yang seakan apa yang disampaikannya adalah suatu kebenaran yang nyata. Sehingga, dugaan tersebut dapat membuat orang-orang yang taklid dengan ulama tersebut dapat menjadikan prasangka yang disampaikan oleh ulama tersebut sebagai suatu kenyataan atau setau hal yang benar. Sementara, apa yang disampaikan hanya untuk menjadikan kelompoknya terlihat lebih Islami dan baik dibandingkan kelompok lain. Dalam hal ini, jelas terlihat bahwa

\footnotetext{
${ }^{54}$ M. Quraish Shihab, Tafsir al-Misbah, 606.

${ }^{55}$ Al-Qur'an, Al-Hujurat (49): 12.

${ }^{56}$ Ibid., 609-610.
} 
dakwah yang dilakukan tidak lagi murni untuk menegakkan amar ma'ruf nahi mungkar. Namun, hanya menjadi kendaraan politik untuk mendapatkan kekuasaan.

Ulama sebagai pewairis Nabi hendaklah memberikan contoh dan teladan yang baik bagi umat atau masyarakat pada umumnya, karena ketika ulama sudah tidak bisa memberikan contoh yang baik maka cita-cita Indonesia 2045 tidak akan terpenuhi. Di mana generasi emas berkaitan dengan bagaimana keadaan generasi Indonesia ketika berusia 100 tahun merdeka, dan yang kedua adalah generasi emas dalam penjabaran kata "emas". Sebagai bangsa yang besar dengan modalitas yang sangat luar biasa; baik sumber daya manusia, sumberdaya alam,sumber daya kultural,maupun sumberdaya lainnya. ${ }^{57}$ Hemat penulis, sebagaimana yang sudah diketahui, setidaknya ada beberapa peran ulama untuk keutuhan Indonesia dalam mewujudkan Indonesia 2045 di antaranya:

Mengajarkan pendidikan karakter berbasis spiritual yang baik

Ulama akan menjadi contoh bagi masyarakat karena keteladan sifat dan akhlaknya. jika akhlak ulama baik maka penanaman pendidikan karakter akan terus tumbuh dan menjadi panutan bagi masyarakt Muslim di Indonesia. Sifat piritual lebih berkaitan dengan pengalaman keagamaan yang dianutnya. Generasi spiritual (ulama) menunjukkan kepada generasi muda yang memiliki kualitas kehidupan rohani yang baik,taat menjalankan ajaran agama, taat beribadah dan menjauhkan hal-hal yang di larang oleh agama. Jadi tokoh agama atau ulama di jadikan panutan oleh masyarakat sebagai pembentukan generasi yang islami untuk mewujudkan indonesia yang bemartabat dan bermoral.

Memberikan nasihat-nasihat yang mempersatukan bangsa

Ulama sebagai garda terdepan masyarakat Muslim Indonesia harus memberikan fatwa-fatwa yang positif ketika sedang berdakwah. Tidak patut di pungkiri juga bahwa dakwah dijadikan sebagai tempat perpolitik para ulama. Oleh karena itu, seorang ulama harus menghindari politik yang mengandung ujaran kebencian kepada salah satu pihak. Dengan demikian poitik yang di lakukan oleh ulama harus sehat, harus memberikan sumbangsih positif kepada Indonesia khususnya generasi muda, jika kondisi politik Indonesia sehat maka untuk mewujudkan Indoesia emas 2045 akan tercapaai dengan terciptanya keadilan dan kedamaian satu sama lain.

Mewujudkan amar ma'ruf dan nahi munkar

Karena dengan pengetahuan agama yang dimiliki dianggap mampu untuk memperbaiki tatanan politik yang terlanjur dianggap tidak baik, melalui jalan politik dakwah. Keberadaan ulama dalam negara menjadi pengontrol penguasa dalam menjalankan kekuasaannya. Penguasa dalam negara Islam wajib untuk menjalankan aturan Islam dalam setiap kebijakannya, ulama menjamin supaya penguasa tetap berada

57 Triyono, Menyiapkan Generasi Emas 2045, Seminar Nasional ALFA_VI, Unwidha Klaten, diakses dari https://www.researchgate.net/publication/324029744, pada tanggal 04 Februari 2019. 
di jalan tersebut. Ulama memang tidak memiliki kekuatan untuk menjatuhkan penguasa. Namun, posisi ulama sebagai panutan bagi masyarakat dan simbol pengikat bagi masyarakat, menjadikan ulama mampu mengubah rezim yang berkuasa. Dengan cara mempengaruhi ketaatan masyarakat terhadap penguasa melalui fatwa dan ajaranajarannya dengan bedakwah memberikan fatwa yang tegas kepada pemimpin-pemimpin muslim untuk tidak memakan uang rakyat (korupsi) agar kehidupan negara Indonesia ini akan terus berkemajuan dan cita-cita mewujudkan Indoenesia emas 2045 dengan para pmimpin yang amanah.

\section{PENUTUP}

Perspektif Al-Qur'an tentang peran ulama di dalam dunia politik bukanlah suatu perkara yang terlarang. Kehadiran mereka diharapkan dapat membawa memberikan citra positif terhadap politik yang telah terlanjur mendapatkan stereotip negatif oleh publik. Agama memberikan pedoman tentang nilai-nilai yang harus ditegakkan dalam undang-undang negara terutama dalam perkara Hak Asasi Manusia (HAM). Sedangkan politik merupakan alat yang untuk mendapatkan kekuasaan agar nilai-nilai agama tersebut dapat diterapkan. Selain itu, media politik sebagai alat untuk berdakwah menanamkan nilai-nilai Islam kepada masyarakat dipandang sah-sah saja, sebagaiman firman Allah, misalnya, Q.S. Ali Imran (3): 104. Maka, tidak dibenarkan apabila seseorang yang dianggap ulama, mudah melakukan cacian dan mengolok-olok orang yang dianggapnya lawan (tidak sejalan) dengan dirinya.

\section{DAFTAR PUSTAKA}

Naim, Ngainun . "Abdurrahman Wahid: Universalisme Islam dan Toleransi." Jurnal Kalam, No. 10, vol. 2 (Desember, 2016): 423-444.

Suseno, Franz Magnis. Agama, Keterbukaan dan Demokrasi: Harapan dan Tantangan. Jakarta: Pusat Studi Agama, 2015.

Haboddin, Mohtar. "Menguatnya Politik Identitas di Ranah Lokal." Jurnal Studi

Pemerintahan, vol. 3, no. 1 (Februari, 2012): 116-134.

Khaerudin, Imawan. “Jurnalisme Data Resistensi Ruang Siberdi Era Post Truth", Jurnal Signal Unswagati Cirebon, vol. 6, no. 2, (Desember, 2018): 1-18.

Simandjuntak, Deasy. "Indonesia: Politik Identitas Bayangi Pilpres 2019" dalam https://www.matamatapolitik.com/indonesia-politik-identitas-bayangi-pilpres-2019/ accessed 02 February 2019.

Sumandoyo, Arbi. "Pilpres 2019: Ulama Sana Versus Ulama Sini." Dalam https://tirto.id/pilpres-2019-ulama-sana-versus-ulama-sini-cRT4, diakses pada 02 Februari 2019.

Hasan, Nor. Studi Islam Kontemporer. Pamekasan: STAIN Pamekasan, 2009.

Hasbiansyah, O. "Pendekatan Fenomenologi: Pengantar Praktik Penelitian dalam Ilmu Sosial dan Komunikasi." Jurnal Mediator, vol. 9, no. 1, (2008): 163-180. 
Sofiandi, dan Imam Hanafi. "Desekularisasi Ulama: Makna Ulama menurut Nurcholis Majid." Jurnal Madania, vol. 8, no.2, (Desember, 2018): 181-200.

Arnawati, Aar. "Kedudukan dan Peran Ulama dalam Perspektif Al-Qur'an: Studi Komparatif Tafsir Al-Qur'ān al-Azìm dan Tafsir Fi Zilāl al-Qur'ān." Jurnal Al-Fath, vol.11, no1, (Juni, 2017): 1-20.

Wahidin, Ade. "Konsep Ulama Menurut Al-Qur'an." Al-Tadabbur: Jurnal Ilmu Al-Qur'an dan Tafsir, vol.1, no.1, (Juli, 2014): 38-56.

Aswar, Hasbi. "Pengaruh Ulama dalam Politik di Negara Muslim: Studi Kasus Arab Saudi." Jurnal Ilmu Sosial Indonesia, vol. 2, no.1, (Maret, 2015): 85-102.

Fuller, Graham E. Apa Jadinya Dunia Tanpa Islam: Sebuah Narasi Sejarah Alternatif, Terj. T. Hermay. Mizan: Bandung, 2014.

Hadi, Anuri Furqan. "Ulama dalam Pandangan Masyarakat Jakarta: Sebuah Pemaknaan Berdasarkan Ruang." Karsa, vol. 20, no.1, (2012): 108-126.

Iyubenu, Edi A.H. Islam yang Menyenagkan: Etika Kemanusiaan sebagai Puncak Keimanan dan Keislaman. Yogyakarta: IRCiSoD, 2017.

Mahadi, Ujang. "Komunikasi Politik Kiai pada Kampanye Pemilu." Addin, vol. 9, no. 2 (Agustus, 2015): 230-252.

Lubis, H.M. Ridwan. Sosiologi Agama: Memahami Perkembangan Agama dalam Interaksi Sosial. Jakarta: Prenada Media Grup, 2015.

Kusuma, Bayu Mitra A. "Negosiasi Dakwah dan Politik Praktis: Membaca Orientasi Organisasi Sayap Keagamaan Islam Pada Partai Nasionalis." Al-Balagh: Jurnal Dakwah dan Komunikasi, vol. 2, no. 1, (Juni, 2017): 1-24.

Nuha, Ulin. "Peran Politik Kiai Dalam Proses Politik di Partai Politik (Studi Kasus Peran KH. A. Haris Shodaqoh Di Partai Persatuan Pembangunan." Politika: Jurnal Ilmu Politik, vol. 3, no. 2, (Mei. 2013): 29-37.

Asroni, Ahmad. "Dakwah dan Politik: Menakar Kontribusi Organisasi Islam Sayap Partai Politik Bagi Masyarakat Muslim Yogyakarta." Jurnal Dakwah, vol. 14, no. 1 (Mei, 2013): 2750.

Fitri Ramdhani Harahap. Politik Identitas Berbasis Agama. Proceeding Konferensi Nasional Sosiologi III Transformasi Demokrasi Indonesia Menuju Perubahan Yang Bermakna Yogyakarta, 20-22 Mei 2014, 511-512.

Zahrotunnimah, "Sejarah Politik Identitas dan Nasionalisme Di Indonesia", Jurnal Al'Adalah, vol. 2, no. 10, (2018).

Purwanto. "Politik Identitas dan Resolusi Konflik Transformatif", Review Politik, vol. 6, No. 1 (Juni, 2015): 60-83.

Kurniawan, Budi. "Politisasi Agama di Tahun Politik: Politik Pasca-Kebenaran di Indonesia dan Ancaman bagi Demokrasi", Jurnal Sosiologi Agama, vol. 12, no. 1 (2018): 133154.

Qutb, Sayyid. Tafsir Fi Dzilalil Quran, vol. 1. Jakata: Gema Insani Press, 2003.

Shihab, M. Quraish. Tafsir al-Misbah: Pesan, Kesan, dan Keserasian al-Qur'an, Jakarta: Lentera Hati, 2012. 
Nurdin, Ali. Qur'anic Society: Menelusuri Konsep Masyarakat Ideal dalam Al-Quran. Jakarta: Penerbit Erlangga, 2006.

HAMKA. Tafsir al-Azhar. Jakarta: Pustaka Panji Mas, 1983.

Triyono, Menyiapkan Generasi Emas 2045, Seminar Nasional ALFA_VI, Unwidha Klaten, diakses dari https://www.researchgate.net/publication/324029744, pada tanggal 04 Februari 2019. 